\title{
Index of political instability in Brazil, 1889-2009
}

\author{
Jaime Jordan Costantini and Mauricio Vaz Lobo Bittencourt
}

ABSTRACT

This article aims to develop an index of political instability (INS) in Brazil between 1889 and 2009, reflecting a wide-ranging set of multiple phenomena that represent conflicts between the different social groups. By presenting different definitions of what is understood by political instability in the economics literature and by using multiple historical events - coups d'état, civil conflicts, constitutional or unconstitutional overthrow and changes in the composition of $50 \%$ of the ministerial cabinet- different indicators are obtained which are then synthesized into a single index using the principal component technique, to obtain an INS for Brazil between 1889 and 2009. Development Unit (NEIDE) of the Federal University of Paraná (UFPR), Brazil. jordan_costantini@hotmail.com Mauricio Vaz Lobo Bittencourt is a Professor for the Graduate Studies Program in Economic Development of the Federal University of Paraná (UfPR), Brazil. mbittencourt@ufpr.br 


\section{I}

\section{Introduction}

To gain a better understanding of the economic development process in individual countries, the economics literature generally uses theoretical and empirical models that do not have a clear definition of the important role of political instability in the development process. Moreover, no account is taken of the historical role of instability, and the empirical studies rely on ceteris paribus-type assumptions to analyse their results.

It is extremely important not only to find ways to make studies of economic development more realistic, but also to provide stronger support to the empirical analyses undertaken, with theoretical, empirical and data models that fill the shortcomings in question -in particular the difficulty of incorporating institutional and historical variables into the analyses-. Such variables can manifest themselves in the country's political stability, or instability, which merely reflect processes of institutional change over time - processes that simultaneously affect and are affected by economic variables.

Economists are very keen to understand the relations that exist between political instability and economic activity in individual countries. There has been much theoretical and empirical research on the economic effects of instability, and the main studies can be summarized in terms of three approaches.

The first approach studies the effects of political instability on the economy by explaining fiscal-policy cycles. Studies of this type include those of Rogoff and Sibert (1988); Alesina and others (1992); Alesina and Tabellini (1990); Edwards and Tabellini (1991); Cukierman, Edwards and Tabellini (1992), and Bohn (2003). These highlight three main effects of political instability on the economy: (i) political instability generates suboptimal public policies since policymakers are uncertain of their own permanency in the government and they manipulate the macroeconomy as a tool in the struggle for power; (ii) entrepreneurial investment decisions are hampered by a climate of political instability in which governments implement suboptimal policies, and (iii) this instability causes interruptions in production, which reduces total factor productivity (TFP).

The second approach investigates the relations that exist between political instability and economic growth, by modelling power conflicts between the social classes and the effects of such conflicts on capital accumulation. Research in this category includes Annett (2001); Devereux and Wen (1998), and Woo (2005), who apply economic theory to study the effects of power conflicts in societies that are unequal and ethnically polarized or divided.

The third approach involves empirical research. The key studies in this category include those of Barro (1991 and 1996), who used panel-data techniques to study the effects of political instability on economic growth in samples of countries. Several recent studies use the generalized method of moments (GMM) to deal with endogeneity problems, including Aisen and Veiga (2011) who attempt to identify the channels through which political instability manifests itself in the economic structure.

Other empirical studies are of a regional type and analyse the topic in relation to a set of countries. The leading examples include Solimano (2003), who analysed political instability in Andean countries, using a variety of variables (change of constitution, presidential crises and volatility of democracy) to explain the deficient performance of their institutions. There are also national studies, such as Evia, Laserna and Skaperdas (2008) on the effects of social protests in the Bolivian economy, which caused a drop in output of several percentage points, and Muñoz (2009), who found that political instability is one of the main causes of the declining trend of economic activity in the Bolivarian Republic of Venezuela.

The aim of the present study is to fill some of the gaps mentioned above, by calculating an index of political instability (INS) in Brazil between 1889 and 2009. An index of this type will make it possible to analyse the main trends of political instability in Brazil's history, and to relate political phenomena to those that are strictly in the economic domain. The index could be used in a variety of future studies to gain a better understanding of the Brazilian development process, because it embraces the political, social, historical and institutional dimensions as well as the economic one.

This article is organized into six sections including the introduction. Section II discusses the different definitions of political instability and appropriate methods for measuring it. Section III describes the historical context of political instability in Brazil, and section IV presents the methodology used. Section V includes the results and the time series of political instability in Brazil between 1889 and 2009, while the last section contains the final thoughts of the article. 


\section{II}

\section{What does political instability mean?}

The specialist literature contains the two definitions of political instability. The first of these sees instability as the propensity for the government to be replaced before the end of its legal mandate, whether through constitutional or unconstitutional means. This definition is applied by Cukierman, Edwards and Tabellini (1992).

The second definition, used by Annett (2001) and Aisen and Veiga (2011), among others, views political instability as resulting from a set of multiple phenomena representing conflicts between different social groups. The phenomena in question could be civil wars, coups d'état, violent protests or new constitutions, or other events; and they are generally measured as categorical variables. This definition of political instability offers a better representation of the country's political evolution, because it reflects a complex process determined by a broad and diverse set of phenomena that affect that instability.

Episodes of political instability in Brazil have often been linked to social and political changes such as those that occurred in the so-called Vargas Era. In such cases, the elements of political instability are associated with a varied set of multiple political and social phenomena, which makes the second definition of political instability more appropriate.

When political instability is related to multiple factors, statistical techniques need to be applied to develop a single variable representing the political instability of the set of factors in question. The appropriate statistical technique for that purpose is principal component analysis, which has been applied by Annett (2001) and Aisen and Veiga (2011).

\section{III}

\section{Historical context of political instability in Brazil between 1889 and 2009}

At the close of the nineteenth century, Portuguese colonialism had bequeathed four organizational legacies that were to prove very persistent and would characterize the profile of institutions in Brazil:

(i) The delegation of significant functions to the localauthority level (Fausto, 1996), thereby perpetuating the pragmatism of the colonial power in the Brazilian empire. Article 66 of the Constitution of 24 February 1822 expressly authorized the states to borrow, organize their own military forces, and impose taxes by decree on their merchandise exports.

(ii) A high concentration of land ownership, structured in large extensive areas, ${ }^{1}$ an institution that originated in the later colonialism of the hereditary "sesmaria"-

\footnotetext{
${ }^{1}$ According to Fausto (1996, pp. 24-26), although the discovery of Brazil by Pedro Álvarez Cabral occurred in 1500, colonization as such began in 1549; and it was consolidated in 1763 with the foundation of the first capital in the city of Salvador, Bahia.
}

based and "capitanias" (colonial land management districts) or land grants to the colonists. ${ }^{2}$

(iii) Colonialism and mercantilism as the defining characteristics of Brazil's international engagement. The colonies had to contribute to the economy of the metropolis in certain areas, with the exclusion of other colonial powers. ${ }^{3}$ Surpluses for export came from forced labour obtained from the indigenous population and, later, from negro slavery. The cycles of mercantilism were associated with certain regions of Brazil and specific export products, such

\footnotetext{
2 The creation of the sesmarias gave rise to the latifundio or estate system, which concentrated political power and a governing class in the economy in a way that would have lasting effects in Brazil.

${ }^{3}$ In the case of Brazil, colonial exclusiveness was less strict because of the impossibility of imposing it and the fact that the trade centres were outside Portugal. In the sixteenth century, the Netherlands participated in the colonial benefits, and, in the seventeenth century, England also entered the colonial scheme.
} 
as Pernambuco (in the sixteenth century); exports of sugar from the North-East (in the sixteenth century, supported by the Netherlands); or the State of Minas Gerais with exports of gold and diamonds (in the seventeenth and eighteenth centuries, as a key development for Portugal). ${ }^{4}$ Other commodities (tobacco and rubber) became alternative crops; and coffee production began in the mid-nineteenth century, initially in Rio de Janeiro and later in São Paulo, which would trigger major transformations in Brazil.

(iv) A tradition of forced labour from Indians and Afro-descendants, which came to an end in 1880, so the Brazilian power elites had to encourage immigration by foreigners for coffee growing. According to Maddison (2008), between 1880 and 1913, a total of 2.7 million foreigners arrived in Brazil (half of them Italians, 700,000 Portuguese and 400,000 Spanish, in addition to smaller numbers of other nationalities). For a country that had 17 million inhabitants at the turn of the twentieth century, those migration figures are highly significant.

\section{The First Republic and the Oligarchic Pact between 1889 and 1929}

The concentration of land ownership, in conjunction with the presence of a skilled immigrant labour force and opportunities for coffee production in São Paulo, fuelled the desire to establish a political power structure that favoured the interests of the power elites. Another factor was the new Liberal Constitution of 1891, which gave the states autonomy from federal power, thereby making it possible to introduce measures to enhance coffee growing, which was fundamental for the State of São Paulo.

The oligarchic pact between the political elites was based on coffee and the spread of urbanization in São Paulo, Rio de Janeiro, Belo Horizonte, Bahia and Porto Alegre. Politically, the elites of São Paulo and Minas Gerais held national power alternately, under the so-called "café com leite" politics based on the interests of coffee-growers and dairy farmers, respectively.

The preponderance of coffee-grower interests in defining the economic policy of the time gave an unorthodox economic orientation to public affairs, owing to the expansionary effects on public expenditure of policies to sustain the coffee price. Nonetheless, the

\footnotetext{
${ }^{4}$ Portugal's trade deficit with England was paid with gold that came from Minas Gerais.
}

international bankers that participated in the plan to defend the coffee price demanded greater rigour in the management of public resources to guarantee credit solvency. Moreover, the states that did not participate in the oligarchic pact had different interests than those of the coffee growers of the state of São Paulo. Consequently, during that period, unorthodox economic policies alternated with more liberal ones, reflecting the concern for fiscal balance, inflation, and the viability of the balance of payments.

Management of the oligarchic pact was rendered more complex by the emergence of both economic and political problems. The most significant economic problem was the crisis of 1929 , which had effects on two fronts. As from 1926, Brazil found it more difficult to obtain the external credits needed to maintain the coffee price, owing to the restrictive policies that had been implemented in the United States to control the speculative bubble on Wall Street. In 1932, coffee prices were $30 \%$ lower than in 1929, and coffee represented about $70 \%$ of Brazil's exports. The political problem was the breakup of the oligarchic pact which enabled the leader of the State of Rio Grande do Sul, Getúlio Vargas, to seize power with a military coup.

\section{Economic changes between 1930 and 1964}

In 1930, under Vargas' leadership, a reform process was launched in the political organization of Brazil, which would last 15 years. The fundamental element of the reforms in question involved the centralization of government power, which brought the states' high level of autonomy to an end. The reforms gave rise to conflicts that led to the outbreak of the Constitutionalist Revolution (or Paulista war) of 1932. The structure of the state was reformed by expanding its sphere of action in the economy, and numerous public institutions were created. The new laws gave broader recognition to workers' rights, and the minimum wage was established; but the right to strike was heavily restricted. The role of industry in the economy was highlighted with the creation of the National Iron and Steel Corporation (Compañía Siderúrgica Nacional) in Volta Redonda, and tools were created to promote industrialization through the Brazilian Development Bank (BNDES). The authoritarian rule of Getúlio Vargas between 1937 and 1945, consolidated changes that would have lasting effects in Brazil. During the World War II, difficulties in obtaining goods and raw materials from abroad provided favourable conditions for an import substitution policy, which contributed to the country's modernization. 
With the end of the Vargas government, the Third Republic was inaugurated along with the period of populist democracies that would last from 1945 to 1964. During that period, the Vargas legacy was consolidated in the form of pro-industrialization policies with robust state support. Between 1945 and 1961, the economy grew rapidly thanks to a positive international context (Abreu, 2000). Nonetheless, economic trends changed ${ }^{5}$ during the government of João Goulart (19621964); and in that period, various political problems arose, which culminated in the military coup of March 1964.

\section{Military rule between 1964 and $\mathbf{1 9 8 5}$}

The historical context of the different governments that succeeded each other in power between 1964 and 1985 can be divided into three stages: (i) the first, between 1964 and 1967, was characterized by the attempt to achieve basic equilibrium in the economy (mainly in terms of inflation); (ii) the economic-miracle period from 1967 to 1979 , and (iii) a period of stagnation between 1979 and 1985.

The Government's Program of Economic Action (PAEG), between 1964 and 1967, was an inflation control plan to correct the balance of payments deficits. During those years, inflation was brought under control gradually, as GDP grew moderately. In the economic-miracle years from 1967 to 1979 , per capita GDP grew by $6.2 \%$ per year, despite external problems caused by the rise in oil prices, and an aggravation of the situation after 1982 when high international interest rates made it difficult to finance the balance of payments. During this period, deep domestic imbalances were compounded by high domestic inflation and a perception of fragility in the alliances that provided the political underpinning for military rule. As a political response, a democratic transition process was launched, starting with the government of President Geisel in 1979. This would culminate in the handover of power to a civilian government under an indirect electoral system introduced by the last military president, João Baptista Figueiredo, in 1985 .

\footnotetext{
${ }^{5}$ Gross domestic product (GDP) grew by $8.6 \%$ in 1961; but in 1963 growth was just $0.63 \%$, and industrial output shrank by $0.2 \%$. Inflation, measured by the General Price Index-Domestic Supply (IGP-DI)/ Getúlio Vargas Foundation (FGV), was 30.5\% in 1960 and $47.8 \%$ in 1961, and it reached a level of $92.1 \%$ in 1964 .
}

\section{Democratic government since 1985}

The transition to democracy was a complex and lengthy process, owing to at least three challenges among the issues included on the political agenda. The economic problem was one of these and seemed to be the most urgent. The second was the need perceived by large segments of society for a new constitution to replace the existing one, whose clearly authoritarian characteristics were the legacy of military rule. The third challenge was to address the heavy social debt in terms of income distribution, which had resulted from the economic policies applied in the two decades of military rule - a debt that needed to be resolved to smooth the harsh contours of Brazil's social reality-. It should be noted that the working class played a major role in promoting the democratic process, thanks to its high degree of organization and power, which could not be ignored by the Brazilian political class.

Although the Brazilian political system in 1985 involved the main leaderships and political powers in the country and had democratic institutions, it was unable to address these three challenges rapidly and simultaneously. Describing the paths of the solutions implemented for each challenge goes beyond the scope of this article, but the solutions finally adopted by Brazilian society are briefly summarized below.

In 1988, a new democratic Constitution was approved, which reclaimed the legacy of the Vargas Era. A major role was given to the State both in the economy and in society; and equity criteria were established in relation to gender, income and regional differences.

The process of solving the country's economic problems was long and tortuous; and there were six failed economic stabilization plans before Brazil found the way to overcome the problem of inflation in 1994 with the Real Plan. This solution was ultimately consolidated in President Fernando Henrique Cardoso's second term of office. Nonetheless, even with democracy, output growth remained unsatisfactory, because, between 1980 and 2008, per capita GDP grew by just $0.77 \%$ per year, which suggests the presence of obstacles to rapid growth in Brazil.

In the social domain, significant progress was made, thanks to government policies that reduced extreme poverty; but progress on income distribution was limited, and public policies still have a long way to go. Major investments are also required in the areas of health, education, infrastructure and security; and the historical need for reforms in both the political and tax systems still persists. 


\section{IV}

\section{Methodology}

The methodology applied includes definition of the variables, information sources, the resulting databases, and the statistical techniques used to synthesize political instability in Brazil in a single index.

\section{Definition of the variables}

Political instability is measured through several indicators and is considered to exist in a given year if any of the following conditions are fulfilled:

(i) Interruption of the President's constitutional mandate $(n c)$. In any given year, the constitutional mandate is not fulfilled, owing to the resignation, constitutional or otherwise, of the President of the Republic. In this situation, the president-elect does not take office owing to an unconstitutional act or some other event. It occurs when the presidentelect dies before taking office, or owing to a force majeure event that prevents the President from taking office, or when the President is unable to fulfil his or her mandate because of a coup.

(ii) A change in 50\% the ministerial cabinet $(m g)$. This variable represents the number of times in the year that the head of government changes half of the ministerial cabinet.

(iii) Change of constitution $(\mathrm{mc})$, owing to the approval of a new constitution or constitutional reforms.

(iv) Civil wars or organized acts of violence for political purposes $(g c)$. Violence is deemed to be organized if more than 100 citizens participate in it. This is a variable measured dichotomously: $g c=1$ in the event of a civil war, acts of violence, or irregular military forces; otherwise $g c=0$.

(v) Labour strikes (greve). This is measured as the number of strikes, normalized on the interval [0.1]. This article makes an innovation with this variable compared to the main known indices, which are generally based on the number of political strikes. The innovation reflects the fact that workers' rights in Brazil were restricted for many years (during the Vargas Era as from 1937 and, in recent times, between 1964 and 1973). After those periods, there were many strike movements in which it is hard to differentiate the political and economic factors.

To determine the value of the five indicators mentioned, information is needed on the constitutional mandate, the taking of office of the president-elect, changes in the cabinet, the approval of new constitutions and reform of existing ones, civil wars, and the number of strikes. The annex includes a detailed list of the information sources used.

\section{Basic concepts of the principal component technique}

Using data on the variables defined above ( $n c, m g, m c$, $g c$ and greve), the multivariate principal component technique is applied to obtain a synthetic vector of political instability in Brazil in the period 1889-2009.

According to Gurmu, Rilstone and Stern (1999), the principal component technique is a multivariate statistical approach that reduces a large number of variables to fewer dimensions. It is particularly useful when the variables considered are correlated. The principal component method creates uncorrelated indices. From a mathematical point of view, with an initial set of $n$ correlated variables, the principal component technique creates uncorrelated components, each of which consists of a weighted linear combination of the initial variables. For example, for a set of variables $X_{1}, \ldots \ldots, X_{n}$, the following components are defined:

$$
\begin{aligned}
& C P_{1}=a_{11} X_{1}+a_{12} X_{2}+\ldots+a_{1 n} X_{n} \\
& C P_{2}=a_{21} X_{1}+a_{22} X_{2}+\ldots+a_{2 n} X_{n} \\
& C P_{n}=a_{n 1} X_{1}+a_{n 2} X_{2}+\ldots+a_{n n} X_{n}
\end{aligned}
$$

where $a_{m n}$ represents the weight of the principal component $m$ of the variable $n$. Each principal component (CP) is weighted by the auto-vector of the correlations matrix if the original data are normalized. The variance of each $\mathrm{CP}$ is the eigenvalue corresponding to each eigenvector. The components are ranked from the first component $\mathrm{CP}_{1}$ (1), which explains most of the original value, subject to the constraint that the sum of the squares of the weights must be equal to one, in other words, $a^{2}{ }_{11}+a^{2}{ }_{12} \ldots+a^{2}{ }_{n n}=1$. The second principal component $\mathrm{CP}_{2}$ (2), explains a smaller proportion of the variation of the original value and is not correlated with (1). Each CP captures a smaller proportion of the principal. This makes 
it possible to reduce to a single index, using the eigenvalues of the corresponding eigenvector as the weighting factor.

Technically, as the principal component describes a set of variables in terms of another smaller set of variables, the method identifies " $n$ " linear combinations of the "n" columns of the $X^{T} X$ matrix $\left(X^{T}\right.$ is the transposed matrix), which are mutually orthogonal and have the property that the first principal component $p_{1}$ minimises $\operatorname{tr}\left(X-p_{1} a_{1}\right)^{T}\left(X-a_{1} p_{1}\right)$, where $\operatorname{tr}$ denotes trace and $a_{1}$ is the eigenvector of $X^{T} X$ associated with the eigenvalue. The second principal component $p_{2}$ is obtained by

\section{V}

\section{Results}

This section presents the descriptive statistics of the database used, the analyses made of the results of the principal component and, lastly, an analysis of the behaviour of Brazilian political instability.

\section{Descriptive statistics}

The results include preparation of the matrix of the values of the variables for all years considered (see annex A.6). The correlations matrix shown in table 1 serves as an illustrative indicator to analyse the relations between the indicators used.

TABLE 1

Brazil: matrix of correlations between the variables related to political instability, 1889-2009

\begin{tabular}{llllll}
\hline & $m g$ & $n c$ & $m c$ & $g c$ & greve \\
\hline$m g^{\mathrm{a}}$ & 1 & & & & \\
$n c^{\mathrm{b}}$ & 0.0065 & 1 & & & \\
$m c^{\mathrm{c}}$ & 0.1587 & 0.3115 & 1 & & \\
$g c^{\mathrm{d}}$ & -0.0038 & -0.0804 & 0.1059 & 1 & \\
greve $^{\mathrm{e}}$ & 0.1608 & 0.0252 & -0.0901 & -0.2416 & 1 \\
\hline
\end{tabular}

Source: prepared by the authors.

a $m g$ indicates changes of $50 \%$ of the composition of the ministerial Cabinet.

b $n c$ refers to interruption of the President's constitutional mandate.

c $m c$ reflects changes in the Constitution.

d $g c$ refers to civil wars and organized acts of violence.

e greve refers to strikes.

Note: the total number of observations is 120 and the significance level is $5 \%$.

The data show a significant positive correlation between the interruption of the constitutional mandate minimising $\operatorname{tr}\left(X-p_{1} a_{1}-p_{2} a_{2}\right)^{T}\left(X-a_{1} p_{1}-p_{2} a_{2}\right)$, where $a_{2}$ is the eigenvector associated with the second eigenvalue. This second component represents the factors that are not represented by the first one. Following this logic, each CP captures the variance of the previous one, which will be represented by its eigenvalue. It can be shown that the contribution to reducing the variability of the CP is $\operatorname{tr}(X)^{\mathrm{T}}(X)-\delta_{1}$, where $\delta_{1}$ is the highest eigenvalue.

The following section describes the application and analysis of the technique to produce an indicator of political instability for Brazil. $(n c)$ and changes in the Constitution $(m c)$. This finding may indicate that changes to existing constitutions and the creation of new constitutions in Brazil were preceded by changes of government outside of a legal mandate. It could also mean that constitutional reforms are seen as acts that create a new order, owing to political movements that use force, the main exception to this being the 1988 Constitution. There is a negative correlation between episodes of organized violence ( $g c$ ) and strikes (greve) As noted above, strikes tended to be recurrent when workers rights were not fully upheld in previous periods.

Table 2 reports the results of the application of the principal component method in the decomposition of the eigenvalues and eigenvectors. The eigenvectors are presented in their orthonormal form, uncorrelated and normalized, with a dimension that is compatible with the five variables used.

It can be seen that $\mathrm{CP}_{1}$ explains a major share of the sample variance. In terms of the eigenvectors, the most important variables are the creation of new constitutions and constitutional reforms, and the interruption of constitutional mandates.

The first principal component was used to obtain the political instability index (INS), giving rise to the following system:

$$
\begin{gathered}
\text { INS }=0.2781 * m g+0.5982 * n c+0.7260 * m c+ \\
0.1712 * g c-0.1352 * \text { greve }
\end{gathered}
$$

From the result of the estimations, an INS is obtained for each year (see table A.6).

Figure 1 shows the trend of this index between 1889 and 2009. 
TABLE 2

Brazil: correlation of the principal components of political instability, 1889-2009

\begin{tabular}{lcccc}
\hline Component & Eigenvalue & Difference & Proportion & Cumulative \\
\hline Component 1 & 1.35551 & 0.04836 & 0.27110 & 0.27110 \\
Component 2 & 1.30714 & 0.27947 & 0.26140 & 0.53250 \\
Component 3 & 1.02768 & 0.31784 & 0.20550 & 0.73800 \\
Component 4 & 0.70984 & 0.11000 & 0.14200 & 0.88000 \\
Component 5 & 0.59983 & - & 0.12000 & 1.00000
\end{tabular}

Principal components (eigenvectors)

\begin{tabular}{|c|c|c|c|c|c|c|}
\hline Variable & $\mathrm{CP}_{1}$ & $\mathrm{CP}_{2}$ & $\mathrm{CP}_{3}$ & $\mathrm{CP}_{4}$ & $\mathrm{CP}_{5}$ & Not explained \\
\hline$m g^{\mathrm{a}}$ & 0.2781 & 0.3575 & 0.7532 & -0.3190 & 0.3594 & 0 \\
\hline$n c^{\mathrm{b}}$ & 0.5982 & 0.1967 & -0.4888 & 0.2140 & 0.5703 & 0 \\
\hline$m c^{\mathrm{c}}$ & 0.7260 & -0.0246 & 0.0400 & -0.0819 & -0.7812 & 0 \\
\hline$g c^{\mathrm{d}}$ & 0.1712 & -0.6031 & 0.4217 & 0.6371 & 0.1524 & 0 \\
\hline greve $^{\mathrm{e}}$ & -0.1353 & 0.6849 & 0.1200 & 0.6632 & -0.2417 & 0 \\
\hline
\end{tabular}

Source: prepared by the authors.

a $m g$ indicates changes of $50 \%$ in the composition of the ministerial Cabinet.

b $n c$ refers to interruption of the President's constitutional mandate.

c $m c$ reflects changes in the Constitution.

d $g c$ refers to civil wars and organize acts of violence.

e greve refers to strikes.

Note: the total number of observations is 120 ; components $=$ trace $=5$.

FIGURE 1

Brazil: index of political instability (INS), 1889-2009

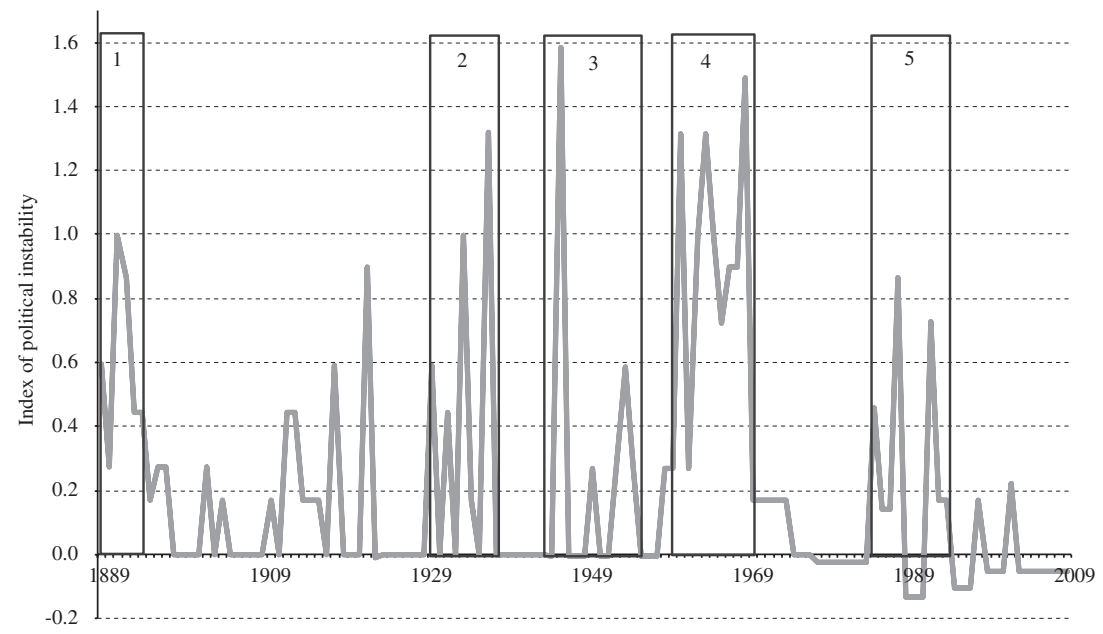

Source: prepared by the authors (see annex A.6).

Note: periods of high political instability are highlighted, numbered from one to five.

Figure 1 shows the INS for Brazil between 1889 and 2009. The higher the index value, the greater is political instability. The INs index was smoothed using the three-year moving average to identify the major trends in political instability in Brazil, and periods of major instability are highlighted.

The analysis of figure 1 shows that Brazil had periods of great political instability but those years were not predominant in the country's history.

\section{Analysis of political instability}

Figure 1 indicates five periods of political instability in Brazil, which are analysed in the following paragraphs.

1889-1894. The First Republic was initially accompanied by a period of major political instability. President Marechal Deodoro da Fonseca dissolved Parliament, in violation the Constitution that had just been promulgated in 1891. This measure was the result 
of disagreements between Deodoro da Fonseca and the coffee-growing elite. In the end, the President resigned to avoid a civil war, and Vice President Floriano Peixoto, another military man, took office as the second President of Brazil in 1892. Under the Constitution of 1891, elections should have been convened nine months later, but this did not happen. As a result, President Peixoto faced several organized military uprisings, but managed to overcome all rebellions until March 1894, when his term of office came to an end.

At the same time as these conflicts were unfolding, the Federalist Revolution occurred in the southern state of Rio Grande do Sul, which caused much bloodshed and ended in 1895. Lastly, between 1895 and 1897 the War of Canudos also caused a large number of fatalities.

The economic context in that period was characterized by a significant downward trend in the price of rubber (then the country's main export product).

Following a period of political instability, the military gave up power and recognized the electoral victory of Prudente de Morais, a coffee grower from São Paulo, thereby launching the period of "café com leite" politics, in which the political leaders of São Paulo and Minas Gerais alternated in power.

These phenomena together make it possible to identify a period of high political instability at the start of the First Republic. The index prepared records a mean of 0.601 , with a standard deviation of 0.271 and a maximum of 0.997 .

1895-1930. These years are not highlighted as a period of extreme political instability in figure 1, despite quite intense instability related to certain economic factors. From the standpoint of those factors, the start of the new century heralded a recovery in the international economy, which had a positive effect on Brazil. Castelar and others (2001) show that the investment rate in Brazil rose from $4.9 \%$ of GDP in 1901 to $17.8 \%$ in 1909 . Much of that investment was channelled into infrastructure and manufacturing industry. Between 1901 and 1914, the railway network expanded by $4 \%$, and electric power generation capacity grew by 13 times. During the World War I, however, investment retreated and the terms of trade declined. Then, between 1918 and 1922, that situation was reversed, when Brazilian exports doubled in two years. In 1923, global business cycles changed again, and Brazil faced a balance of payments crisis and high inflation (31\% per year), which led to orthodox economic policies being implemented throughout the presidency of Artur Bernardes.

At the same time, dissatisfaction among middleranking military officers was reflected in events such as the Copacabana Fort revolution in 1922 and, subsequently, the Coluna Prestes revolt. A state of siege prevailed throughout the Bernardes presidency, with the consequent restrictions on political freedoms.

The Vargas Era (1930-1945). The changes that occurred in Brazil during this period represented a response to "café com leite" politics by the elites of certain states (particularly Rio Grande do Sul and Paraíba), which were competing for power. The period known traditionally as the Vargas Era encompassed the following administrations: (i) the provisional government of 1930-1934, which emerged from the civil and military uprising of 1930 and gave rise to the new Constitution of 1934; (ii) the government of President Vargas between 1934 and 1937, of democratic type, resulting from popular election; (iii) the Estado Novo (New State) dictatorship from 1937 to 1945 , during which a new constitution was approved in 1937, and which ended in a coup d'état in 1945, and (iv) the constitutional government of Getúlio Vargas, which began in 1951 and ended with his suicide in 1954. The Vargas Era was based on a centralized state and strong executive, which profoundly changed the "oligarchy pact" of the First Republic, and constituted a significant source of conflict. President Vargas used the new Constitution of 1937 as a mechanism to institutionalize that change, while closing down Congress and decreeing that governors would be subject to the President's authority.

There were episodes of instability throughout that period, including the civil and military uprising of 1930 , the constitutional Paulista War of 1932, the installation of the Estado Novo dictatorship in 1937, the military overthrow of Getúlio Vargas in 1945, and his subsequent suicide in 1954.

Political instability between 1945 and 1964. These years are known as the period of populist democracy, owing to the succession of governments that maintained the legacy of the Vargas Era involving development supported by the State, in an international scenario that was propitious for policies of that type. This enabled Brazil to achieve a per capita GDP growth rate of around $4.5 \%$ per year, along with a substantial degree of industrial diversification. At the end of the government of Juscelino Kubitschek, signs of economic imbalance appeared in the form of high inflation rates, and in 1961 Brazil entered a process of political instability that intensified in the ensuing years.

1961-1970. This was the longest-lasting period of political instability in Brazil, in which the Brazilian Constitution was changed five times. Although there were phases of rapid economic growth, the profound 
difficulties in dealing with the major economic imbalances in Brazil were also clear to see. Political instability began with the resignation of Jânio Quadros in 1961, and his replacement by Vice President João Goulart. The government of President Goulart suffered from internal instability and continuous changes in its ministerial composition. At the same time, there was growing popular urban and rural mobilization in the struggle to reform the structure of the Brazilian State in favour of the less privileged classes. Conservative groups and the middle-class resisted the changes and supported the military uprising of 1964 . The military government phase began in 1964 with a provisional project, but it subsequently defined long-term policies as from 1969. During many of the military governments of that period, there was organized resistance in the form of guerilla movements which, despite not putting military rule at risk, represented a factor of political unrest. During the mandate of Ernesto Geisel, the military began a lengthy and costly process of transition to democracy.

Democratic transition (1985-1994). This period was complex. The death of President-elect Tancredo Neves and the swearing-in of Vice President José Sarney meant that, from the outset, the New Republic displayed great fragility in facing the economic problems inherited from the last military government. In addition to economic difficulties, the new government had to implement reforms to democratize the State. In 1988, Brazil's seventh constitution was approved, the most democratic of its history, which incorporated the "Getulista ideal" and protected Afro-descendants and women from discrimination. Between 1985 and 1995, ministers of finance were very unlikely to still be in their post one year after taking office. As a result, Brazil had 11 finance ministers $^{6}$ in 10 years. The political instability in 1992 was caused by the constitutional overthrow of President Fernando Collor following an impeachment process.

Between 1995 and 2009, Brazil experienced the longest period of political stability in its modern history, largely thanks to the macroeconomic equilibrium achieved by the government of President Fernando Henrique Cardoso and consolidated during the mandate of President Luís Inácio da Silva.

Table 3 provides a summary of the results obtained with the INs, indicating the periods of greatest instability (1889-1894, 1895-1930, 1931-1945, 1961-1970 and 19851994) and the respective means and standard deviations of the INs. This shows that the greatest instability occurred between 1961 and 1970, followed by the period 18891894, and the process of democratic transition. Thus, apart from the period of the First Republic, political instability is a characteristic of modern Brazil.

\footnotetext{
${ }^{6}$ The 11 finance ministers were: Francisco Oswaldo Neves Dornelles, Dílson Domingos Funaro, Luiz Carlos Bresser Gonçalves Pereira and Maílson Ferreira da Nóbrega (in the government of José Sarney); Zélia Maria Cardoso de Mello and Marcílio Marques Moreira (in the government of Fernando Collor), and Paulo Roberto Haddad, Eliseu Resende, Fernando Henrique Cardoso, Rubens Ricupero and Ciro Ferreira Gomes (in the government of Itamar Franco).
}

TABLE 3

Brazil: values of the political instability index (INS) during the main episodes of instability, 1889-1994

\begin{tabular}{|c|c|c|}
\hline Period & Mean/standard deviation of the INS & Episodes of instability \\
\hline 1889-1894 & $0.600 / 0.278$ & $\begin{array}{l}\text { - Deodoro da Fonseca dissolved Parliament } \\
\text { - Floriano Peixoto took office and did not call new elections } \\
\text { - Constitutional military uprisings against Floriano Peixoto }\end{array}$ \\
\hline $1895-1930$ & $0.132 / 0.217$ & $\begin{array}{l}\text { - Federalist War in Rio Grande do Sul } \\
\text { - War of Canudos } \\
\text { - Copacabana Fort Revolution } \\
\text { - Coluna Prestes revolt }\end{array}$ \\
\hline $1931-1945$ & $0.194 / 0.413$ & $\begin{array}{l}\text { - Civil and military coup led by Getúlio Vargas } \\
\text { - Constitutions of } 1934 \text { and } 1937 \\
\text { - Dissolution of Congress and declaration of the Estado Novo } \\
\text { - Paulista War of } 1932 \\
\text { - Military coup against Getúlio Vargas in } 1945\end{array}$ \\
\hline $1961-1970$ & $0.906 / 0.430$ & $\begin{array}{l}\text { - Resignation of Jânio Quadros } \\
\text { - João Goulart took office } \\
\text { - Frequent changes of more than } 50 \% \text { of the Cabinet } \\
\text { - Public demonstrations for and against the reforms of the State } \\
\text { - Coup d'état of } 1964 \\
\text { - Amendment of the Constitution (five times) } \\
\text { - Promulgation of Institutional Act No. } 5 \text { (AI-5) } \\
\text { - Presence of armed insurgent movements }\end{array}$ \\
\hline
\end{tabular}


Table 3 (conclusion)

\begin{tabular}{ll}
\hline Period & Mean/standard deviation of the INS Episodes of instability \\
\hline $1985-1994$ & - Death of President-elect Tancredo Neves \\
& - Impeachment of President Fernando Collor \\
& - Continuous changes of Finance Minister \\
& - Six failed economic stabilization plans
\end{tabular}

Source: prepared by the authors.

\section{Statistical correlation between the INS and a selection of economic variables}

This subsection describes the indicators of statistical correlation between the INS and certain economic variables, with the aim of assessing whether each indicator is related to other variables in the logically expected direction. In addition, the intensities of the calculated correlations are evaluated.

The economic indicators chosen were the level of GDP, investment, the terms of trade, inflation, international crises, the fiscal deficit, and population. As the indicator produced spans a lengthy time series, covering the period 1889-2009, various sources of information were used, with series covering a large number of years.

For the output series, the study by Maddison (2008) was used, which contains Brazilian GDP data from 1870 to 2007. GDP data were also obtained from the Brazilian Geographical and Statistical Institute (IBGE)-Histórico, which contains data between 1900 and 2007. Apart from that information, IBGE-Histórico provides data on investments and the terms of trade in those periods. Another information source was the study by Heston, Summers and Aten (2008), which includes data on output and investments from 1950 to 2007, identified in table 4 as Penn World Tables (PWT). Data on inflation and international crises was taken from Rogoff and Reinhart (2011) on Brazil as from 1830. In the case of the fiscal deficit, the 1900-2007 series available on the Ipeadata website was used. The original sources of those data are the Ministry of Finance. The fiscal deficit indicator was used to calculate the deficit as a percentage of GDP estimated by IBGE-Histórico.

Having different sources for a given variable, as in the case of output, made it possible to compare the different estimations and thus obtain more robust conclusions.

Table 4, below, shows the correlation coefficients and highlights the different information sources. As the Heston, Summers and Aten (2008) data start in 1950, it was decided to present the correlation coefficients from the other sources, particularly those of Maddison (2008), IBGE-Histórico, and Rogoff and Reinhart (2011) in comparable periods.
The analysis of table 4 was performed in decreasing order of the indicators chosen. A negative relation was found between political instability and output. In the case of longer periods, that correlation does not seem very significant. Nonetheless, considering the period since 1950, the correlation is significant, and the three information sources display similar results. The difference in correlation between the two periods shows that, in the years of Brazil's modernization, political instability had more pronounced effects in terms of reducing output. A more detailed and in-depth analysis of that phenomenon would go beyond the scope of this article; but it should be noted that the phenomenon is reflected in the three information sources.

A negative correlation can also be discerned between investment and political instability, which is almost nonexistent in the IBGE-Histórico series considering almost the entire period; but that situation changes when only the more recent period between 1950 and 2009 is considered. The behaviour of investment in Brazil in the two subperiods is interesting. From 1900 to 1950 , the average investment rate was $10.5 \%$ of GDP, with a maximum of $20.3 \%$ of GDP and a minimum of $4.21 \%$. Between 1950 and 2007, the average investment rate was $18.4 \%$, with extreme values of $12.8 \%$ and $26.9 \%$ of GDP. In the most recent period, investment represented a major share of aggregate demand and, therefore, its behaviour should more closely match variations in output and the domestic and external shocks to the Brazilian economy. This possibly explains the higher correlation that exists between investment and political instability in more recent periods.

It is interesting to evaluate the correlation between the international terms of trade and political instability, because negative shocks on the international markets for Brazil's export products serve as one of the channels through which political instability is transmitted. That assessment was made using an indicator of changes in the terms of trade in a given year in relation to the previous one. Account was also taken of the volatility of the terms of trade, which, for a given year, is equal to the standard deviation of the terms of trade index in the five previous years, divided by the average terms of 
TABLE 4

Brazil: correlation coefficient between the INS and a selection of economic variables, 1889-2007

\begin{tabular}{|c|c|c|c|}
\hline Sources/variables & Years & Number of years & Correlation coefficient \\
\hline \multicolumn{4}{|c|}{ GDP } \\
\hline Maddison & $1889-2007$ & 118 & $-0.1771 * *$ \\
\hline IBGE-Histórico & $1901-2007$ & 106 & $-0.1431 * * *$ \\
\hline Penn World Tables (PWT) & $1950-2007$ & 57 & $-0.4475^{*}$ \\
\hline Maddison & $1950-2007$ & 57 & $-0.4698 *$ \\
\hline IBGE & $1950-2007$ & 57 & $-0.4611 *$ \\
\hline \multicolumn{4}{|c|}{ Investment } \\
\hline IBGE-Histórico & $1901-2007$ & 106 & -0.0154 \\
\hline IBGE-Histórico & $1950-2007$ & 57 & -0.2447 \\
\hline$P W T$ & $1950-2007$ & 57 & -0.1315 \\
\hline \multicolumn{4}{|c|}{ Terms of trade } \\
\hline Terms of trade variation & $1905-2007$ & 102 & -0.0403 \\
\hline Terms of trade volatility & $1905-2007$ & 102 & $-0.1848 * * *$ \\
\hline Terms of trade volatility & $1950-2007$ & 57 & -0.1619 \\
\hline World output & $1889-2007$ & 118 & $-0.147 * * *$ \\
\hline World output & $1950-2007$ & 57 & $-0.4124^{*}$ \\
\hline \multicolumn{4}{|c|}{ Inflation } \\
\hline Variation in prices & $1889-2007$ & 118 & -0.045 \\
\hline Variation in prices & $1950-2007$ & 57 & -0.073 \\
\hline \multicolumn{4}{|c|}{ Financial crises } \\
\hline Financial crises & $1889-2007$ & 118 & $0.1371 * * *$ \\
\hline Financial crises & $1950-2007$ & 57 & $0.2109 * * *$ \\
\hline \multicolumn{4}{|c|}{ Federal fiscal deficit } \\
\hline Federal fiscal deficit & $1900-2007$ & 107 & $-0.0807 * *$ \\
\hline Federal fiscal deficit & $1950-2007$ & 57 & -0.0691 \\
\hline Government income & $1900-2007$ & 107 & $-0.2271 *$ \\
\hline Government income & $1950-2007$ & 57 & $-0.3717 *$ \\
\hline Government expenditure & $1900-2007$ & 107 & $-0.2082 *$ \\
\hline Government expenditure & $1950-2000$ & 57 & $-0.3596^{*}$ \\
\hline \multicolumn{4}{|c|}{ Population } \\
\hline Population & $1889-2007$ & 118 & $-0.148 * * *$ \\
\hline & $1950-2007$ & 57 & $-0.412 *$ \\
\hline
\end{tabular}

Source: prepared by the authors, on the basis of A. Maddison (2008), The World Economy: Historical Statistics, Paris, OECD Development Centre, 2008 [online] http://www.ggdc.net/maddison/; A. Heston, R. Summers and B. Aten, "Penn World Tables Version 6.1", Center for International Comparisons at the University of Pennsylvania, 2008 [online] http://pwt.econ.upenn.edu/, and K. Rogoff and C. Reinhart, "From financial crash", American Economic Review, vol. 101, No. 5, Nashville, Tennessee, American Economic Association, 2011.

INS: political instability index.

*Statistical significance at $1 \%$; **statistical significance at 5\%; ***statistical significance at $10 \%$.

trade of the five previous years. Thus, terms-of- trade volatility in a given year reflects the variability of the terms of trade in the five preceding years, for which reason the volatility series begins in 1905 . The definition of volatility and the data were obtained from the IBGEHistórico database. Another measure considered as an alternative indicator of Brazil's international economic situation is the level of economic activity in the most important countries, namely the average GDP per capita of the United States, Germany, the United Kingdom and Japan. This indicator was obtained from the Maddison (2008) database. All of the indicators suggest that the variation in the international terms of trade is only weakly correlated with the INS. In contrast, terms- of-trade volatility has a more significant effect; and, doubtless, the economic activity level of the most important countries is also clearly correlated with political instability.

The correlation between the INS and inflation has the expected sign, but it is small in value and not statistically significant. As the Brazilian economy has a very long track record of living with inflation, it would be somewhat risky to assert that the Brazilian economy displayed political instability in the years of highest inflation. It would be more appropriate to say that a political crisis was caused by inflation in years containing hyperinflationary episodes, in other words, in the period 1988-1994 in the Brazilian case. 
The indicator of financial crises produced by Rogoff and Reinhart (2011) refers to four types of financial crisis: a crisis of the exchange rate and high inflation, cessation of payment on the government's external and domestic debts, stock market crashes and banking crises. Each of these crises is evaluated as a categorical variable, taking the value 1 when the phenomenon is present in a given year and zero otherwise. Lastly, the authors establish a synthesis variable by adding together the different types of crises defined. Table 4 uses that synthesis variable which summarizes the four types of financial crisis. In principle, there should be a positive correlation between the financial crisis indicator and the INS index, the results of which are shown in table 4 . As is the case with other indicators used in table 4, the effects of financial crises are more closely correlated with political instability since 1950 . The average of the financial crises between 1889 and 2007 is 1.44 . The most significant feature of the Rogoff and Reinhart (2011) series is that the series average rises from 0.95 in the period 1889-1950 to 1.96 in the subsequent period. This means that financial crises in Brazil have been far deeper in more recent years. The maximum value of the financial crisis indicator was 6 in 1986, according to the financial crisis index estimated by Rogoff and Reinhart (2011). In that year, all types of crisis defined by the authors were present in Brazil. It is highly significant that, in the period running from the external debt crisis in Mexico in 1982 to the launch of the Real Plan in Brazil in 1994, the financial crisis indicator was 3.9, the highest level in Brazil's financial history for more than a century.

Another indicator used was the correlation between the INS and the fiscal deficit as a percentage of GDP.

\section{VI}

\section{Final thoughts}

In the various lines of research, it is important to take account of the interaction that exists between social, economic and political variables. When seeking to understand a country's political and economic trajectory, this kaleidoscopic view may be particularly necessary to explain the causes of the successes (and the failures) of its development process.

As many studies on the Brazilian economy ignore this complex historical interaction, mainly because there is no single variable that encompasses all of these dimensions consistently, the present study set out to
If there was a deficit, the fiscal deficit indicator was negative. Bearing in mind that the greater the political instability the greater is the estimated index, there should be a negative relation between the two indicators. Table 4 reports a negative correlation between the fiscal deficit and political instability, which weakened slightly between 1950 and 2007. The variation between the two periods reflects the fact that Brazil systematically recorded fiscal deficits from 1900 to 1950. Fiscal balance was only attained in nine of those years, and there were deficits in the other 41 years. Between 1950 and 2009, however, the opposite was the case: only 20 deficits in that period, and just three since 1976. This was the result of the counterinflationary policies applied in those years, based on fiscal rigour. The correlations between public expenditure and government income, on the one hand, and political instability, on the other, are clearer.

Lastly, the correlation between population and the INS is calculated, to analyse whether population growth in the country, with all of the phenomena that that implies, is related to political instability. The result is that there is in fact a negative correlation between population and the INS.

The calculation of the correlation indicators presented above leads to the following conclusions: (i) the estimated index and the chosen economic variables are correlated, and in the expected direction; (ii) those results are robust, because the indicators calculated using data from different sources produce similar results, and (iii) the correlation is stronger since 1950, which was the period in which the country began a modernization process and acquired greater productive complexity.

construct an INS for Brazil for the period 1889-2009, based on the principal component statistical technique.

The index produced is deemed to capture the main cycles of political instability in Brazil's history. Moreover, the analysis of the series shows that those cycles correspond only to certain years, so, Brazil is a country with a low level of political instability.

The authors consider that this research makes a positive contribution by constructing an INS for Brazil for the first time, which could be used in various studies to fill a historical and empirical gap in the literature. 
ANNEX

\section{Sources of information on the variables}

\section{A.1 Variable: Interruption of constitutional mandate (nc)}

To quantify this variable, the following criteria and information sources were used:

(i) Characteristics of the period of the constitutional mandate for the President and rules on his replacement, set out in detail in annex A.3.

(ii) Different events that represent the interruption of the President's constitutional mandate $(n c)$.

- 1889: coup d'état by Deodoro da Fonseca against the Emperor Dom Pedro II.

- 1892: coup d'état by Floriano Peixoto against Deodoro da Fonseca.

- 1918: death of President-elect Rodríguez Alves, who never took office.

- 1930: civil and military uprising of Getúlio Vargas.

- 1937: Getúlio Vargas declares himself dictator.

- 1946: Getúlio Vargas is deposed.

- 1954: suicide of Getúlio Vargas.

- 1961: resignation of Jânio Quadros.

- 1964: military coup.

- 1969: death of Costa Silva and his unconstitutional replacement by a military junta.

- 1985: death of President-elect Tancredo Neves.

- 1992: constitutional overthrow of President Fernando Collor de Mello.

\section{A.2 Change of $50 \%$ of the composition of the cabinet $(\mathrm{mg})$}

To generate quality statistics with this variable, it is necessary to know the number of ministers in all periods studied and their names; in addition to the number of times those changes exceeded half of the number of ministers in a given year.

To establish the number of ministries, a list was prepared in creation date order, indicating changes in name and the year of extinction. This information is shown in table A.2.

These data were used to prepare a list of the number of ministries that operated under each President of Brazil from 1889 to 2009, in other words the 34 people who officially took office as President of the Republic. The list does not include the governmental juntas of 1930 and 1969, or the three presidents-elect who never took office (Júlio Prestes, Rodríguez Alves and Tancredo Neves), the first of these because of the military uprising in 1930, and the other two because they died.
No account was taken of changes in the ministerial cabinet of the following provisional governments:

- Governmental Junta (1930), from 24 October 1930 to 3 November 1930.

- José Linhares (1945), from 29 October 1945 to 31 January 1946.

- $\quad$ Carlos Luz (1955), from 8 November 1995 to 11 November 1955.

- $\quad$ Nereu Ramos (1955), from 11 November 1955 to 31 January 1956.

- Provisional governments of Ranieri Mazzilli of 1961 (25 August 1961) and 1964 (from 2 April 1964 to 15 May 1964).

- Provisional governmental junta (1969), from 31 August 1961 to 30 October 1969.

For each government, the name of the ministers was determined and the date on which they began and ended their functions, as well as a number of ministers there have been since the foundation of the Republic. For example, Rui Barbosa was the first Minister of Finance of Brazil, in the government of Deodoro da Fonseca, and was thus assigned No. 1, whereas Guido Mantega, Finance Minister in the government of President Luís Inácio Lula da Silva is No. 71. This listing made it possible to precisely identify all of the ministers and ministries existing during each presidential term. The list of ministries excluded the Ministry of De-bureaucratization, which was short lived, created on 18 July 1979 and abolished on 14 February 1986. Nor did it include the Ministry of Administrative Reform created during the mandate of President Fernando Collor de Mello, which was discarded by his successor, President Itamar Franco.

If the number of changes of minister in a given year exceeded half of the total number of ministries, a situation of political instability was inferred to exist in that year. For the purposes of this study, replacement by an interim minister was not considered as a change of ministers. If, in any one ministry, there were two or more changes in a given year, those changes are counted as separately. In the cases of President Fernando Henrique Cardoso and President Luís Inácio Lula da Silva, both of whom served a second term, the changes in each mandate were considered separately. In other words, in the year in which the President took office for a new mandate, the change of minister between the end of the first mandate and the start of the second was not considered as a change of minister for the purposes of this study.

Lastly, changes in secretariats and other institutions of ministerial status were not counted. The only exception 


\begin{tabular}{|c|c|c|}
\hline & Ministry & Year of creation \\
\hline 1 & Ministry of Finance (MF) & 1808 \\
\hline 2 & Ministry of Justice (MJ) & 1822 \\
\hline 3 & Ministry of Foreign Relations (MRE) & 1852 \\
\hline 4 & Ministry of Agriculture and Food Supply (MA) & 1909 \\
\hline 5 & Ministry of Transport ${ }^{\mathrm{a}}$ (MT) & 1861 \\
\hline 6 & Ministry of Marine Affairs ${ }^{\mathrm{b}}$ (мM) & 1891 \\
\hline 7 & Ministry of the Army ${ }^{b}$ (ME) & 1891 \\
\hline 8 & Ministry of Work and Employment (MTE) & 1930 \\
\hline 9 & Ministry of Aeronautics ${ }^{b}$ (MAER) & 1941 \\
\hline 10 & Ministry of Health (MSAU) & 1953 \\
\hline 11 & Ministry of Development, Industry and Foreign Trade ${ }^{c}(\mathrm{MD})$ & 1960 \\
\hline 12 & Ministry of Mines and Energy (MME) & 1960 \\
\hline 13 & Ministry of Planning (MPL) & 1962 \\
\hline 14 & Ministry of Communications (MC) & 1967 \\
\hline 15 & Ministry of the Environment (MMA) & 1973 \\
\hline 16 & Ministry of Social Welfare (MPS) & 1974 \\
\hline 17 & Ministry of Culture (MCUL) & 1985 \\
\hline 18 & Ministry of Science, Technology and Innovation (Мтст) & 1985 \\
\hline 19 & Ministry of Tourism (MTUR) & 1992 \\
\hline 20 & Ministry of Sports (MES) & 1995 \\
\hline 21 & Ministry of National Integration (MINT) & 1999 \\
\hline 22 & Ministry of Agricultural Development (MDA) & 1999 \\
\hline 23 & Ministry of Defence (MD) & 1999 \\
\hline 24 & Ministry of Cities (MCIDADES) & 2003 \\
\hline 25 & Ministry of Aquaculture and Fisheries (MPESC) & 2003 \\
\hline 26 & Ministry of Social Development Fight against Hunger (MFOME) & 2004 \\
\hline
\end{tabular}

Source: prepared by the authors.

a This ministry has had several names. 1860-1891: State Secretariat of Agribusiness, Commerce and Public Works; 1891-1906: Ministry of Industry, Roads and Public Works; 1906-1967: Ministry of Roads and Public Works; 1967-1990: Ministry of Transport; 1990-1992: Ministry Infrastructure; 1992-1992: Ministry of Transport and Communications; and 1992-2012: Ministry of Transport.

b Abolished under a Complementary Law 97 of 10 June 1999, which created the Ministry of Defence.

c Ministry abolished between 1990 and 1992.

to that rule was the Ministry of the Casa Civil (Office of the Chief of Staff of the Presidency of the Republic), which was created on 3 November 1930 as the Secretariat of the Presidency of the Republic and became the Casa Civil on 1 December 1938. This decision was taken because the Casa Civil Minister is an institution of great political importance in Brazil, with functions similar to those of prime minister in a parliamentary regime. ${ }^{7}$

\section{A.3 Changes in the Constitution (mc)}

The analysis of this point is relevant for deciding whether the presidential mandate has been interrupted in accordance with the Constitution. Brazil has had seven constitutions: 1822, 1891, 1934, 1937, 1946, 1967 and 1988; and there have been eight constitutional reforms: 1927, 1961, 1963, 1964-1967, 1967, 1968, 1969 and 1979.

\footnotetext{
7 The result of this uprising is shown in a 70-page annex which, owing to space restrictions, is not included in this article, but is available on request.
}

The key points in each Constitution or constitutional amendment were as follows:

- Presidential mandate according to the Constitution, in number of years.

- Processes for replacing the President if the Presidentelect cannot fulfil the constitutional mandate owing to death or constitutional dismissal.

- The rules through which regimes of exception, arising as a result of the use of force, regulated its presidential succession system. In particular, this was the case of the military governments of 1964 to 1985.

In relation to the issues mentioned, the situation depended on each Constitution:

- Constitution of 1891: the presidential term lasted four years, and the elected president could not stand for a new mandate. In the event of death or resignation of the President, the Vice President took office only until a new vote was held, instead of competing the mandate, as happens now (Brazilian Constitutions of 1891 and 1957). 
- Constitution of 1934: the mandate of the President was four years, and the replacement lasted long enough to organize new elections (Arruda and Caldeira, 1986).

- Constitution of 1937: the mandate was six years with the possibility of re-election (Arruda and Caldeira, 1986).

- Constitution of 1946: the presidential mandate was five years (Montellato, Cabrini and Catelli Jr., 2000).

- Constitution of 1966: the presidential mandate was five years (Montellato, Cabrini and Catelli Jr., 2000).

- Constitutional amendment of 1961: thange from a presidential to a parliamentary system.

- Constitutional amendment of 1963: thange from a parliamentary to a presidential system.

- Constitutional amendment of 1969: treation of a military junta which replaced President Costa Silva.

- Institutional Act No. 1: tonducted a purge of opposition politicians and citizens; governed elections between 1964 and 1967.

- Institutional Act No. 2: dissolved the existing parties and in practice established the two-party system between 1964 and 1967.

- Institutional Act No. 3: instituted the holding of direct elections for the state governments. The mayors (prefeitos) of capital cities and "municipalities of the national security area" where henceforth appointed by the governors in 1964 .

- Institutional Act No. 4: compelled Congress to vote on the draft Constitution of 1967.

- Institutional Act No. 5: dissolved Congress, suspended constitutional guarantees and authorized the executive to legislate on all matters in 1969.

- Constitutional amendment: repeal of Institutional Act No. 5, 1979.

- Constitution of 1988: four-year presidential term: in the event of the death of the President, the vice president took office until the end of the mandate.

Source: http://www.duplipensar.net/dossies/historia-de las-eleicoes.

\section{A.4 Civil wars and acts of organized political violence recorded in the history of Brazil (gc)}

The civil wars or acts of organized violence recorded in Brazilian history are as follows:

- War of Canudos between 1896 and 1897.

- Federalist Revolution between 1893 and 1895.

- Vaccine Revolt of 1904.

- Revolt of the Lash of 1910.

- Contestado War between 1912 and 1916.

- Copacabana Fort Revolution of 1922.
- Paulista Revolution of 1922.

- Constitutionalist Revolution of 1932.

- Communist Uprising (Intentona) of 1935.

- Caparão guerrilla war of 1967.

- Araguaia guerilla war between 1967 and 1974.

Source: J. Schulz, O Exército na política: origens da intervenção militar, 1850-1894, São Paulo, Editora da Universidade de São Paulo (EDUSP), 1994; and E. Seidl, "A formação de um exército à brasileira: lutas corporativas e adaptação institucional", História, vol. 29, No. 2, São Paulo, 2010.

The following events referred to earlier were excluded:

(i) The Vaccine Revolt: excluded because it did not have a defined political objective. It represented popular resistance to the methods of application and generalization of immunization in the city of Rio de Janeiro. This initiative involved the destruction of homes and shanty towns, which caused a climate of popular resistance.

(ii) The Revolt of the Lash: excluded because it involved acts of indiscipline in the Brazilian navy, in response to the brutalities imposed by that institution's hierarchy.

\section{A.5 Strikes (greve)}

Statistics on strikes are based on Noronha (2009) for the years 1978-2007, and on Simão (1981) for earlier years.

TABLE A.5

Brazil: number of strikes, 1888-2002

\begin{tabular}{lc}
\hline Period & No. of strikes per year \\
\hline $1888-1890$ & 2 \\
$1901-1914$ & 9 \\
$1914-1929$ & 8 \\
$1930-1936$ & 12 \\
$1937-1944$ & 1 \\
$1945-1964$ & 43 \\
$1965-1968$ & 13 \\
$1969-1977$ & 0 \\
$1978-1984$ & 214 \\
$1985-1989$ & 102 \\
$1990-1992$ & 1126 \\
$1993-1994$ & 842 \\
$1995-1998$ & 865 \\
$1999-2002$ & 440
\end{tabular}

Source: E.G. Noronha, "Ciclo de greves, transição política e estabilização: Brasil, 1978-2007”, Lua Nova, No. 76, São Paulo, 2009; A. Simão, Sindicato e Estado. Suas relações na formação do proletariado de São Paulo, São Paulo, Editora Ática, 1981.

To evaluate the effect of the strikes, this variable was normalized on the interval [0.1], using the value of each year in relation to the maximum value in the period 1990-1992. 


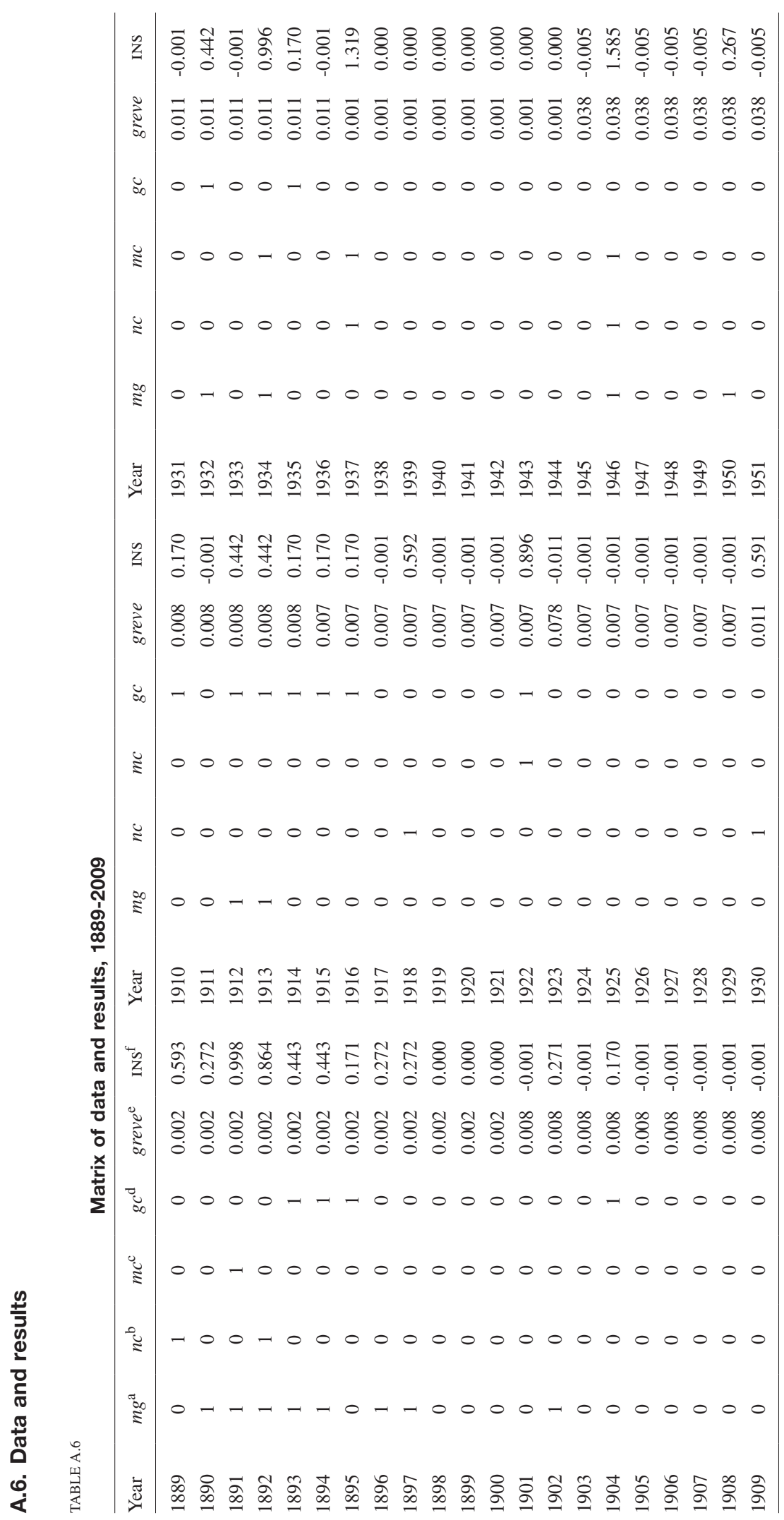




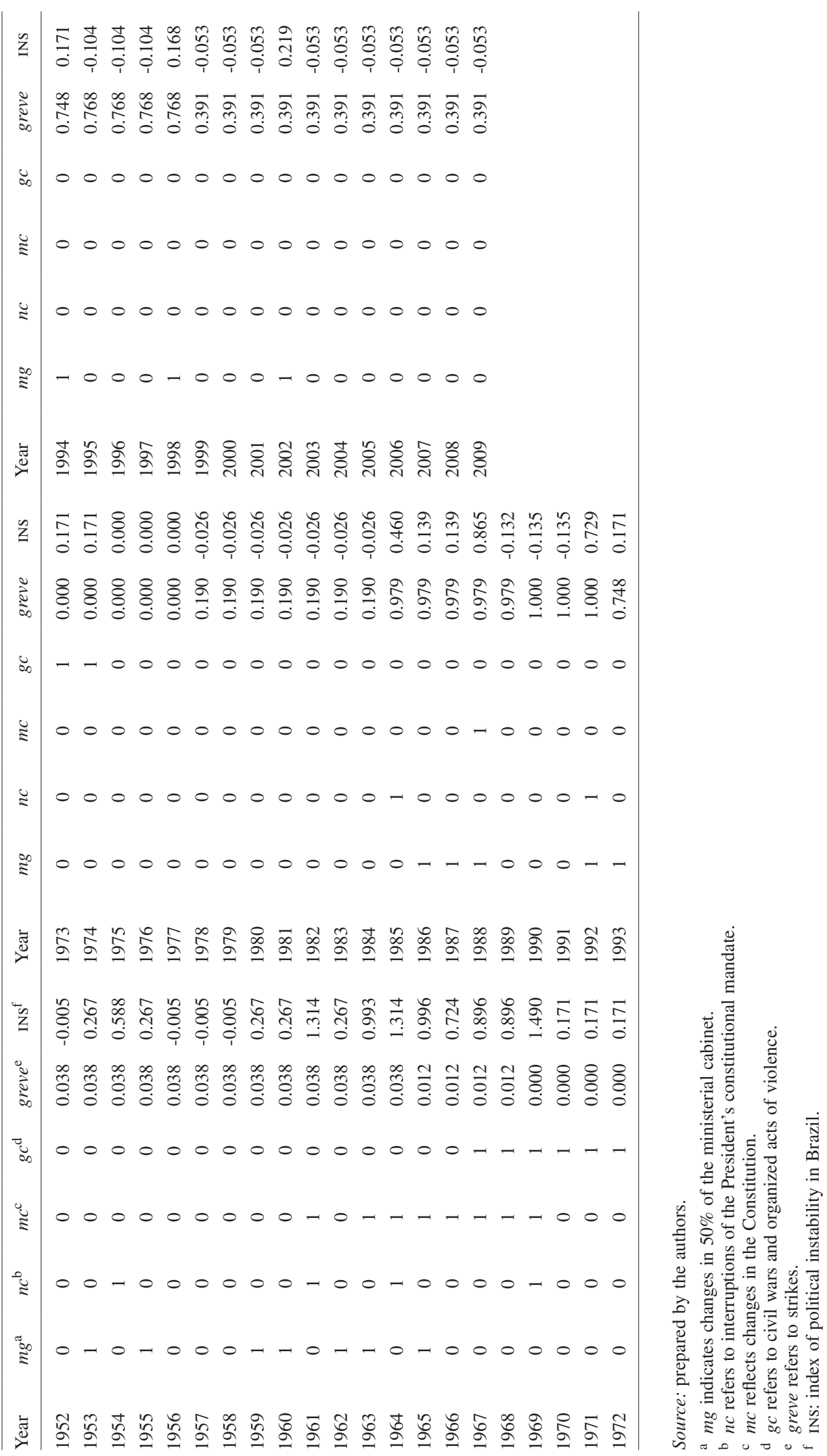




\section{Bibliography}

Abreu, M. de Paiva (2000), "The Brazilian economy, 1928-1980", Texto para Discussão, No. 433, Rio de Janeiro, Department of Economics, Catholic University of Rio de Janeiro. (1999), O Brasil e a economia mundial, 1930-1945, Rio de Janeiro, Civilização Brasileira.

Aisen, A. and F. Veiga (2011), "How does political instability affect economic growth?", IMF Working Papers, No. 11/12, Washington, D.C., International Monetary Fund.

Alesina, A. and G. Tabellini (1990), "A positive theory of fiscal deficits and debt", Review of Economic Studies, vol. 57, No. 3, Oxford, Oxford University Press.

Alesina, A. and others (1992), "Political instability and economic growth", NBER Working Papers, No. 4173, Cambridge, Massachusetts, National Bureau of Economic Research (NBER).

Annett, A. (2001), "Social fractionalization, political instability, and the size of government", IMF Staff Papers, vol. 48, No. 3, Washington, D.C., International Monetary Fund.

Arruda, M. and C. Caldeira (1986), Como surgiram as constituições brasileiras, Rio de Janeiro, Federation of Organizations for Social and Educational Assistance (FASE).

Barro, R. (1996), "Determinants of economic growth: a cross-country empirical study", NBER Working Paper, No. 5698, Cambridge, Massachusetts, National Bureau of Economic Research.

(1991), "Economic growth in a cross section of countries", Quarterly Journal of Economics, vol. 106, No. 2, Oxford, Oxford University Press.

Bohn, F. (2003), "A note on corruption and public investment: the political instability threshold", Economics Discussion Papers, No. 559, University of Essex.

Castelar, A. and others (2001), "Brazilian Economic Growth, 19002000: Lessons and Policy Implications", Rio de Janeiro, draft.

Constituição Brasileira de 1896 (1957), Planalto Central do Brasil, Coleção Documentos Brasileiros, Livraria José Olympio Editora.

Cukierman, A., S. Edwards and G. Tabellini (1992), "Seigniorage and political instability", American Economic Review, vol. 82, No. 3, Nashville, Tennessee, American Economic Association.

Devereux, M.B. and J.F. Wen (1998), "Political instability, capital taxation and growth", European Economic Review, vol. 42, No. 9, Amsterdam, Elsevier.

Edwards, S. and G. Tabellini (1991), "Explaining fiscal policies and inflation in developing countries", Journal of International Money and Finance, vol. 10, Amsterdam, Elsevier.

Evia, J.L., R. Laserna and S. Skaperdas (2008), "Sociopolitical conflict and economic performance in Bolivia",
CESIFO Working Paper Series, No. 2249, Munich, CESIFO Group Munich.

Fausto, B. (1996), História do Brasil, São Paulo, Editora da Universidade de São Paulo (EDUSP).

Gurmu, S., P. Rilstone and S. Stern (1999), "Semiparametric estimation of count regression models", Journal of Econometrics, vol. 88, No. 1, Amsterdam, Elsevier.

Heston, A., R. Summers and B. Aten (2008), "Penn World Tables Version 6.1", Center for International Comparisons at the University of Pennsylvania [online] http://pwt.econ.upenn. edu/.

IBGE (Brazilian Geographical and Statitistical Institute) (n/d), "Séries históricas e estatísticas" [online] http://seriesestatisticas.ibge. gov.br/default.aspx.

Maddison, A. (2008), The World Economy: Historical Statistics, Paris, OECD Development Centre [online] http://www.ggdc. net/maddison/

Montellato, A., C. Cabrini and R. Catelli Jr. (2000), História temática: o mundo dos cidadãos, São Paulo, Ed. Scipione.

Muñoz, R. (2009), "Political instability and economic growth: the case of Venezuela (1983-2000)", Documentos de Trabajo, Caracas, Andrés Bello Catholic University.

Noronha, E.G. (2009), "Ciclo de greves, transição política e estabilização: Brasil, 1978-2007”, Lua Nova, No. 76, São Paulo.

Rogoff, K. and C. Reinhart (2011), "From financial crash", American Economic Review, vol. 101, No. 5, Nashville, Tennessee, American Economic Association.

Rogoff, K. and A. Sibert (1988), "Elections and macroeconomic policy cycles", Review of Economic Studies, vol. 55, No. 1.

Schulz, J. (1994), O Exército na política: origens da intervenção militar, 1850-1894, São Paulo, Editora da Universidade de São Paulo (EDUSP).

Seidl, E. (2010), "A formação de um exército à brasileira: lutas corporativas e adaptação institucional", História, vol. 29, No. 2, São Paulo.

Simão, A. (1981), Sindicato e Estado. Suas relações na formação do proletariado de São Paulo, São Paulo, Editora Ática.

Solimano, A. (2003), "Governance crisis and the Andean Region: a political economy analysis", Macroeconomía del desarrollo series, No. 23 (LC/L.1860-P), Santiago, Chile, Economic Commission for Latin America and the Caribbean (ECLAC). United Nations publication, Sales No. E.03.II.G.33.

Woo, J. (2005), "Social polarization, fiscal instability and growth", European Economic Review, vol. 49, No. 6, Amsterdam, Elsevier. 